\title{
Chemical profile, thermodynamic stability and fungicidal activity of the nanoemulsion incorporated with essential oil and hydroalcoholic extract of Syzygium aromaticum (L.) Merr. \& LM.Perry
}

\author{
Perfil químico, estabilidade termodinâmica e atividade fungicida da \\ nanoemulsão incorporada com óleo essencial e extrato hidroalcoólico \\ de Syzygium aromaticum (L.) Merr. \& LM.Perry
}

\author{
Thaylanna Pinto de Lima'(1), Thayane Lopes de Sousa'(i), \\ Joao Pedro Mesquita Oliveira'(D), Maria Giullia Alves Carneiro Felizardo'(D), \\ Gustavo Oliveira Everton'i(i), Victor Elias Mouchrek Filho'(i) \\ ' Universidade Federal do Maranhão, Laboratório de Pesquisa e Aplicação de Óleos Essenciais \\ Universidade, São Luiz, Maranhão, Brazil
}

\begin{abstract}
This work aimed to evaluate the fungicidal activity of oil-in-water (O/W) nanoemulsions of hydroalcoholic extract andessential oil of sprouts of Syzygium aromaticum. For the extraction of essential oil, the hydrodistillation technique was used. To obtain the hydroalcoholic extract, the process of maceration with solvent extract ethanol methanol P.A 70\% (v / v) was performed. Nanoemulsions were obtained using the low-energy phase inversion method with thermodynamic stability assessed by stress tests. For the fungicidal activity of oil-in-water (O/W) nanoemulsions, the Broth Dilution and Agar Seeding assay was used to determine the Minimum Inhibitory Concentration (MIC) and Minimum Fungicidal Concentration (CFM). The action of the biotechnological product was tested against three strains of fungi Aspergillus niger, Colletotrichum gloeosporioides, Penicillium chrysogenum. For antifungal action of the essential oil nanoemulsion, the MIC obtained was $25 \mu \mathrm{g} \mathrm{mL}^{-1}, 25 \mu \mathrm{g} \mathrm{mL}^{-1}$ and $50 \mu \mathrm{g} \mathrm{mL}^{-1}$ against $A$. niger, C. gloeosporioides and $P$. chrysogenum, respectively, for the hydroalcoholic extract nanoemulsion the result was $50 \mu \mathrm{g} \mathrm{mL}^{-1}, 50 \mu \mathrm{g} \mathrm{mL}^{-1}$ and $100 \mu \mathrm{g} \mathrm{mL}{ }^{-1}$ for $A$. niger, C. gloeosporioides and $P$. chrysogenum, respectively. On the other hand, the CIM dthe nanoemulsion of the essential oil showed activity against A. niger of $25 \mu \mathrm{g} \mathrm{mL}-1$ and against $C$. gloeosporioides it showed inhibition in $25 \mu \mathrm{g} \mathrm{mL} \mathrm{m}^{-1}$ and in the nanoemulsion of the hydroalcoholic extract it had its best performance in front of $A$. niger of $50 \mu \mathrm{gL} \mathrm{mL}^{-}$ ${ }^{1}$ and in front of $C$. gloeosporioides, which showed inhibition in $50 \mu \mathrm{g} \mathrm{mL}^{-1}$. Finally, this study points to the nanoemulsion of S. aromaticum as an alternative fungicide in the control and combat of pathogenic fungi.
\end{abstract}

Keywords: Fungicide; Syzygium aromaticum; Phytochemistry 


\section{RESUMO}

Este trabalho teve como objetivo avaliar a atividade fungicida das nanoemulsões óleo-em-água (O/A) do extrato hidroalcoólico e do óleo essencial de brotos de Syzygium aromaticum. Para extração do óleo essencial utilizou-se a técnica de hidrodestilação. Para obtenção do extrato hidroalcoólico executou-se o processo de maceração com solvente extrato metanol P.A 70\% (v/v). As nanoemulsões foram obtidas pelo método de baixa energia de inversão de fases com a estabilidade termodinâmica avaliada por testes de estresse. Para atividade fungicida das nanoemulsões óleo-em-água $(\mathrm{O} / \mathrm{A})$ utilizou-se o ensaio de Diluição em Caldo e Semeadura em Ágar para determinação da Concentração Inibitória Mínima (CIM) e Concentração Fungicida Mínima (CFM). A ação do produto biotecnológico foi testada frente a três cepas de fungos Aspergillus niger, Colletotrichum gloeosporioides, Penicillium chrysogenum. Para ação antifúngica da nanoemulsão do óleo essencial a CIM obtida foi de $25 \mu \mathrm{g} \mathrm{mL}^{-1}, 25 \mu \mathrm{g} \mathrm{mL}^{-1}$ e $50 \mu \mathrm{g} \mathrm{mL}^{-1}$ frente a A. niger, C. gloeosporioides e $P$. chrysogenum, respectivamente, já para a nanoemulsão do extrato hidroalcoólico o resultado obtido foi de $50 \mu \mathrm{g} \mathrm{mL}^{-1}, 50 \mu \mathrm{g} \mathrm{mL}^{-1}$ e $100 \mu \mathrm{g} \mathrm{mL}^{-1}$ para A. niger, C. gloeosporioides e $P$. chrysogenum, respectivamente. Por outro lado, a CIM da nanoemulsão do óleo essencial apresentou atividade frente a A. niger de $25 \mu \mathrm{g} \mathrm{mL}^{-1}$ e frente ao C. gloeosporioides apresentou inibição em $25 \mu \mathrm{g} \mathrm{mL}^{-1}$ e na nanoemulsão do extrato hidroalcóolico teve a seu melhor desempenho em frente a A. niger de 50 $\mu \mathrm{g} \mathrm{mL} \mathrm{L}^{-1}$ e em frente ao C. gloeosporioides que apresentou inibição em $50 \mu \mathrm{g} \mathrm{mL} \mathrm{m}^{-1}$. Por fim, este estudo aponta a nanoemulsão de $S$. aromaticum como fungicida alternativo no controle e combate de fungos patogênicos.

Palavras-chave: Fungicida; Syzygium aromaticum; fitoquímica

\section{INTRODUCTION}

The use of medicinal plants for the treatment of illnesses has been known since prehistory. In Brazil, the introduction of these plants in healing rituals comes from the indigenous culture, and this empirical knowledge remains today. Approximately $66 \%$ of the Brazilian population without access to modern medicine makes use of popular medicines, often representing the only therapeutic resource for many communities and ethnic groups (MAZZARI \& PRIETO, 2014). Faced with this scenario, the population has been looking for healthier and lower-cost treatments to treat their illnesses. Although modern medicine is well developed in most parts of the world, WHO recognizes that a large portion of the population in developing countries depends on traditional medicine for their primary care (BRASIL, 2006).

The use of plants for medicinal purposes has aroused great interest in the knowledge of the chemical composition of plants (SIMÕES, 2001). In several studies, plants have several biologically active products, supported by the fact that many 
are models for the synthesis of a significant number of drugs. Researchers marvel at the wide variety of these products, however 19 datas show that only 15 to $17 \%$ of plants have been studied for their medicinal potential (MARTINS, 2010).

Among the plants featured, is the species Syzygium aromaticum (L.) Merr. \& L.M.Perry, popularly known as India cloves, has its origins in the Philippines and East Africa (PAHLOW, 2004). The name carnation in Portuguese derives from the Latin word clavus, which means "prego", due to its physical appearance. In English the name clove was derived from the French old clou, which is related to the verb unir -function performed by the nail (ORNELAS, 2000). The clove (Syzygium aromaticum) is a tree, of the Myrtaceae family adapted to the African and Brazilian climate (CARDOSO et al., 2007). Its leaves have oval, aromatic characteristics and are 7-11 centimeters long (LORENZI et al., 2002). Other authors describe it as originating in India, being also found in Indonesia, Zanzibar and Ceylon, with an elongated characteristic.

The species is mainly exploited for industrial extraction of essential oil (EO) obtained from flower buds, leaves and other parts. The popular use of the species refers to flower bud tea as a carminative and stimulant of digestive functions (LORENZI \& MATOS, 2002).

Essential oils are liquid, volatile, clear, rarely colored, fat-soluble or soluble in organic solvents. They can be synthesized by all the organs of the plant and are the result of their secondary metabolism, being characterized by a strong and marked odor. The essential oil of S. aromaticum is used by Ayurvedic medicine, for respiratory treatments and eating disorders. The antiseptic and antibiotic properties are also explored in the preparation of homemade toothpaste and mouthwashes (BANERJEE et al., 2006).

Phytochemical studies of cloves reveal the abundant presence of essential oil, in which eugenol is the major component, accompanied by trans-karyophylene, eugenyl acetate, humulene and vanillin (PAOLI et al., 2007; PEREIRA et al., 2008), 
where studies prove that eugenol has excellent antifungal activity (PARK et al., 2007).

Because they have hydrophobic properties, their application is facilitated through the formulation of nanoemulsions. Recent research reports that the formation of nanoemulsion containing EOs are used as strategies to improve its functionality. Nanoemulsions consist of a very fine dispersion, composed of an oil phase (such as triglycerides or hydrocarbons) and an aqueous phase (water or water) that are presented as drops with a diameter less than $100 \mathrm{~nm}$. They are constituted by a polymeric casing arranged around a nucleus, the active component of interest being able to be dissolved in that nucleus and / or adsorbed to the polymeric wall. The retention of these nuclei is governed by their chemical functionality, solubility, polarity and volatility (GHARSALLAOUI et al., 2007) These systems are believed to have several advantages over conventional emulsions because they are colloidal distribution systems due to their lower particle size. Nanoemulsions appear to have optical transparency, enhanced functionality and physical stability, which would make them very attractive to biotechnology etc. (ASSIS et al., 2012).

Thus, this study aimed to evaluate the phytochemical profile, quantification of total phenolics and flavonoids and evaluation of the fungicidal activity of the essential oil, hydroalcoholic extract and the nanoemulsion formulated with the essential oil and hydroalcoholic extract obtained from the flower buds of Syzygium aromaticum (clove).

\section{METHODOLOGY}

\subsection{Plant material}

The collection of plant material used in this research was carried out from October to December 2020. S. aromaticum were obtained in the municipality of São 
Luís, Brazil. After collection, the plant species were transported to the Laboratory for Research and Application of Essential Oils (LOEPAV / UFMA). The material was sent to for sorting, determination of the water content and drying in a digital convection air oven FANEM 520.

\subsection{Obtaining essential oil}

For the extraction of EO, the hydrodistillation technique was used with Clevenger glass extractor coupled to a round bottom flask wrapped in an electric blanket as a heat generating source. $100 \mathrm{~g}$ of each plant material were used, plus distilled water $(1: 10)$. Hydrodistillation was carried out at $100^{\circ} \mathrm{C}$ for $3 \mathrm{~h}$ and the extracted EO was collected. Each EO was percolated with anhydrous sodium sulfate (Na2SO4) and centrifuged. These operations were performed in triplicates and the samples stored in amber glass ampoules under refrigeration at $4^{\circ} \mathrm{C}$. Subsequently, they were analyzed.

\subsection{Preparation of hydroalcoholic extract}

For the preparation of hydroalcoholic extracts, $100 \mathrm{~g}$ of plant material was used in natura. The maceration process with solvent extract methanol PA 70\% (v / v) was used following the proportion 1:10. The solution obtained after 7 days was filtered and concentrated on a rotary evaporator under reduced pressure, after the process the extract was dried to remove the residual solvent for further analysis (HARBORNE, 1998). The hydroalcoholic extract was subjected to chemical tests based on the methodology presented by Matos (2009).

\subsection{Total phenolics}

The phenol content was determined for essential oils and hydroalcoholic extracts by the Folin-Ciocalteau spectrophotometric method (LUGASI et al., 1998; 
OLIVEIRA et al., 2009). $5 \mathrm{mg}$ of the essential oil diluted in $1 \mathrm{ml}$ of ethanol was used. To this solution was added $7 \mathrm{~mL}$ of distilled water, $800 \mu \mathrm{L}$ of $10 \%$ Folin-Ciocalteu reagent and $2.0 \mathrm{~mL}$ of $7.5 \%$ sodium carbonate. The formed solution was taken to the water bath at $50^{\circ} \mathrm{C}$ for $5 \mathrm{~min}$, removed and left to cool; and then the reading was performed on a manual spectrophotometer, at a length of $760 \mathrm{~nm}$. As a reference, an analytical curve with tannic acid was obtained, which provided the line equation for converting the absorbance measured in milligrams equivalent of tannic acid per gram of extract (mg EAT.g-1).

The hydroalcoholic extract was diluted in ethanol to obtain solutions with a concentration of $10 \mathrm{mg} \mathrm{mL}^{-1}$. To an aliquot of $0.1 \mathrm{ml}$ of each solution, $7.0 \mathrm{ml}$ of water, $0.8 \mathrm{ml}$ of the Folin-Ciocalteau reagent (10\% v/ v) and $1.2 \mathrm{ml}$ of $20 \%$ aqueous $\mathrm{Na} 2 \mathrm{CO} 3$ solution were added. After 2 hours, the absorbances of the samples were measured at $760 \mathrm{~nm}$. As a reference, an analytical curve with tannic acid was obtained, which provided the line equation for converting the absorbance measured in milligrams equivalent of tannic acid per gram of extract (mg EAT.g ${ }^{-1}$ ). The standard curve was expressed in $\mathrm{mg} \mathrm{L}^{-1}$ of tannic acid.

\subsection{Total flavonoids}

To estimate the total flavonoid content, $\mathrm{AlCl}$ complexation was used 3 The content of total flavonoids was estimated spectrophotometrically by reaction with AICI3, using quercetin as a standard (DOWLD, 1959; WOISKY \& SALATINO, 1998; FREDERICE et al., 2010). The extracts and essential oils were diluted in ethanol to obtain solutions with a concentration of $10 \mathrm{mg} \mathrm{mL}^{-1}$. To a $0.2 \mathrm{ml}$ aliquot of this solution, $4.4 \mathrm{ml}$ of EtOH and $0.4 \mathrm{ml}$ of $2 \%$ aqueous $\mathrm{AlCl} 3$ solution were added. After 30 minutes, the absorbances of the samples were measured at $425 \mathrm{~nm}$. As a reference, an analytical curve was obtained with quercetin, which provided the line equation for the conversion of absorbance measured in milligrams equivalent of quercetin per gram of extract (mgEQ.g-1 $)$. 


\subsection{Preparation of nanoemulsions}

The preparation of the nanoemulsions was carried out according to the adapted methodologies described by Lima et al. (2020), Sugumar et al. (2014), Kubitschek et al. (2014) and Rodrigues et al. (2014) observed in Table 1.

Table 1 - Nanoemulsion formulations for Syzygium aromaticum essential oil

\begin{tabular}{lcccc}
\hline Identification & Essential oil (EO) & Hydroalcoholic extract (EH) & Tween 20 & H2O \\
\hline NEO1 & $5 \%$ & - & $5 \%$ & $90 \%$ \\
NEO 2 & $5 \%$ & - & $10 \%$ & $85 \%$ \\
NEO 3 & $5 \%$ & - & $15 \%$ & $80 \%$ \\
NEH 1 & - & $5 \%$ & $5 \%$ & $90 \%$ \\
NEH 2 & - & $5 \%$ & $10 \%$ & $85 \%$ \\
NEH 3 & - & $5 \%$ & $15 \%$ & $80 \%$ \\
\hline
\end{tabular}

Source: Authors (2021)

The oil concentration E. (5\% v / v) and H. Extract ( $5 \% \vee / v)$ were fixed for the formulation. The required amounts of each constituent of the oil phase (oil + Tween20) and (Extract H. + Tween20) were heated to $65 \pm 5^{\circ} \mathrm{C}$. The aqueous phase was heated separately to $65 \pm 5^{\circ} \mathrm{C}$, added gently and mixed with the oil phase, providing a primary formulation, by the phase inversion method. Final homogenization was achieved using a magnetic stirrer, in which the formulation remained in constant agitation at $6000 \mathrm{rpm}$, until the temperature was reduced to $25^{\circ} \mathrm{C} \pm 2{ }^{\circ} \mathrm{C}$.

To prove stability, of the formulated nanoemulsions were subjected to different stress tests according to the methodology described by Shafiq et al., (2007). They were evaluated for phase separation by centrifugation. The heatingcooling cycle was carried out keeping the formulated nanoemulsions at 40 and $4^{\circ} \mathrm{C}$, 
alternating each temperature for $48 \mathrm{~h}$. The cycle was repeated three times. This was done to check the stability of the nanoemulsion at variable temperatures. The freeze-thaw stress was carried out by maintaining the nanoemulsions alternatively at -21 and $25^{\circ} \mathrm{C}$ for $48 \mathrm{~h}$ at each temperature. The cycle was repeated twice. The experiment was carried out in triplicate. The formulations approved in the thermodynamic stress tests were taken for studies of antifungal action.

\subsection{Standardization of the microbial inoculum for sensitivity tests}

Three strains of fungi were used: Aspergillus niger (ATCC 6275), Colletotrichum gloeosporioides (ATCC 96723), Penicillium chrysogenum (ATCC 10106). These were previously identified and confirmed by biochemical tests. Pure cultures maintained on TSA agar were seeded into brain and heart infusion broth (BHI) and incubated at $35^{\circ} \mathrm{C}$ until they reached exponential growth phase (4-6 h). After this period, the cultures had their cell density adjusted in sterile $0.85 \%$ saline, in order to obtain a turbidity comparable to that of the McFarland 0.5 standard solution, which results

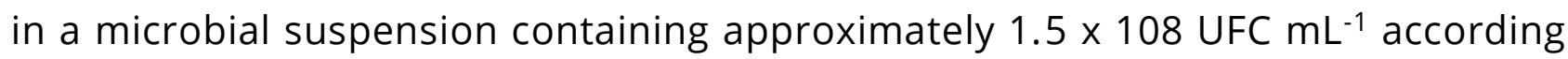
to the standards of the Clinical and Laboratory Standards Institute.

\subsection{Minimum Inhibitory Concentration (CIM) and Minimum Concentration (CFM)}

This test evaluated the Minimum Inhibitory Concentration (MIC) and Minimum Fungicidal Concentration (CFM) of essential oils and hydroalcoholic extracts. The MIC test was performed using the broth dilution technique, proposed by the Clinical and Laboratory Standards Institute. First, EO solutions were prepared using $2 \%$ Tween 20 , and serial dilutions were prepared in $\mathrm{BHI}$ broth for the fungal assay, resulting in concentrations of 10 to $1000 \mu \mathrm{gL}^{-1}$. The nanoemulsions were diluted directly in the culture medium.

To each concentration, fungal suspensions containing $1.5 \times 10^{8} \mathrm{CFU} \mathrm{mL}^{-1}$ of the strains were added. The tubes were incubated at $25^{\circ} \mathrm{C}$ for $24-48 \mathrm{~h}$ for the fungal 
strains. Sterility and growth controls were performed for the test performed. After the incubation period, EO MIC was verified, being defined as the lowest concentration that visibly inhibited fungal growth (absence of visible turbidity). Tests performed in triplicate.

For the CFM assay of dilutions from BHI broth that visibly inhibited fungal growth. The aliquots were inoculated on Sabourad Dextrose Agar (ASD) with subsequent incubation at $35^{\circ} \mathrm{C}$ for $24 \mathrm{~h}$. The CFM was determined as the lowest concentration that visually in the MIC test showed growth inhibition and that in the cultures for the fungicide tests also did not show visible growth.

\section{RESULTS AND DISCUSSION}

\subsection{Phytochemical screening}

The phytochemical analysis of S. aromaticum obtained was performed according to the methodology of Matos et al. (2009). Where, according to the methodology, the following classes of secondary metabolites were detected in Table 2.

Table 2 - Classes of secondary metabolites identified in Syzygium aromaticum

\begin{tabular}{cccccccc}
\hline Classes & $\mathbf{1}$ & $\mathbf{2}$ & $\mathbf{3}$ & $\mathbf{4}$ & $\mathbf{5}$ & $\mathbf{6}$ & $\mathbf{7}$ \\
\hline S. aromaticum & + & + & + & + & - & - & + \\
\hline
\end{tabular}

Source: Authors (2021)

Note: 1: Alkaloids; 2: Cardiac Glycosides; 3: Steroids; 4: Flavonoids; 5: Glycosides; 6: Saponins; 7: phenols; (+) positive; (-negative).

Among the secondary metabolites found in this study, as shown in Table 2, the presence of alkaloids, cardiac glycosides, steroids, flavonoids, phenols stands out. Corroborating with previous studies by the author Teles et al. (2019). Although the pharmacological activity observed for a given extract is usually the result of the synergistic and conjugated effect, some metabolites present in plant extracts can 
account for the majority of biological activity (BESSA et al., 2013). Therefore, it is important to highlight its main biological and pharmacological properties for the classes of metabolites found in this study (COSTA et al., 2018).

The S. aromaticum buds are characterized by the presence of about $20 \%$ volatile oil rich in eugenol with a concentration ranging from 85 to $95 \%$. This essential oil is used in ethnomedicine and continues to be the object of studies due to its wide diversity of pharmacological and biological activities, already described, such as: analgesic, anesthetic, anti-inflammatory and antibacterial (HEMAISWARYA \& DOBLE, 2009).

The alkaloids identified in phytochemical characterization have diverse and important physiological effects on humans and other animals, are found mainly in plants and are especially common in certain families of flowering plants. They are used as poisons and hallucinogens, known for their action on the central nervous system. The presence of alkaloids can be related to a wide range of investigated biological activities. Many indole alkaloids act on opiate neurotransmitter, GABAergic, muscarinic, serotonergic and dopaminergic cholinergic systems, so they are used as hypotensive, sympatholytic, diuretic, peripheral vasoconstrictors, respiratory stimulants, anesthetics, adrenergic blocking agents, intestinal spasmogens, sedatives, intestinal agents

Cardiac glycosides, on the other hand, are drugs used in protocols for the treatment of CHF (congestive heart failure). Symptomatic in class III patients (asymptomatic at rest and symptomatic in less-than-usual activity) and IV (symptomatic presenting dyspnea, resting fatigue and palpitation), in association with other first-line drugs for treatment. Cardiac glycosides do not promote the regression of the disease however, they act positively in the improvement of symptoms, stabilization of the condition and prevention of worsening (SOCIEDADE BRASILEIRA DE CARDIOLOGIA, 2002).

Steroids that tested positive have anti-inflammatory, antibacterial and analgesic action (OLIVEIRA et al., 2016). Steroids form a class of secondary 
metabolites formed by decarboxylations of precursors that originate from triterpenes (RODRIGUES et al., 2010), this can be associated with several pharmacological actions.

In summary, we saw secondary metabolites found in this study and its importance in this way exploration as a biotechnological product is very necessary in view of its vast benefits.

\subsection{Quantification of phenolics and total flavonoids}

The results of the total phenolic and flavonoid content of the essential oil and the hydroalcoholic extract of Syzygium aromaticum are shown in Table 3. The total phenolic content (CPT) of the essential oil and hydroalcoholic extract was expressed as tannic acid equivalents (mg EAT g-1 of plant material) the equation of the line obtained was $y=0.0586 x+0.06\left(R^{2}=0.9999\right)$, where $y$ represents the absorbance of the equivalent tannic acid concentration. For the flavonoids, the quecertin standard (mg EQT g ${ }^{-1}$ of plant material) was used, the equation obtained was $y=0.0033 x+0.0006\left(R^{2}=0.9845\right)$, where $y$ represents the absorbance of the quercetin equivalent concentration.

Table 3 - Quantification of phenolics and total flavonoids in essential oil and hydroalcoholic extract of Syzygium aromaticum

\begin{tabular}{lcc}
\hline \multicolumn{1}{c}{ Phenolics } & Essential oil & Hydroalcoholic Extract \\
\hline Total $(\mathrm{mg}$ EAT $\mathrm{g}-1)$ & 207,615 & 143,589 \\
Linear Equation $(\mathrm{y}=\mathrm{ax}+\mathrm{b})$ & $\mathrm{y}=0.0586+0.06$ & $\mathrm{y}=0.0586+0.06$ \\
Correlation Coefficient $\left(\mathrm{R}^{2}\right)$ & 0.9998 & 0.9998 \\
\hline \multicolumn{1}{c}{ Flavonoids } & EO & EH \\
\hline Total $(\mathrm{mg}$ EQT g-1) & 125.36 & 143.36 \\
Linear Equation $(\mathrm{y}=\mathrm{ax}+\mathrm{b})$ & $\mathrm{y}=0.0033+0.006$ & $\mathrm{y}=0.0033+0.006$ \\
Correlation Coefficient $\left(\mathrm{R}^{2}\right)$ & 0.9845 & 0.9845 \\
\hline
\end{tabular}

Source: Authors (2021) 
According to Table 3, phytochemical studies revealed the presence of phenolic compounds resulting in positive quantity in essential oil 207.6 mg EAT g-1, supporting the following results and scientific studies such as that of Adaramola \&

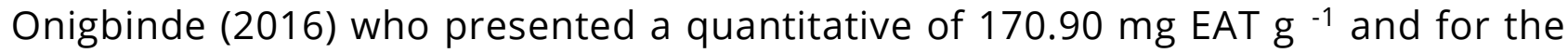
extract It can be said that through this test it is possible to predict a good antioxidant activity, already in reference to the study of Teles et al. (2019).

The presence of phenolic compounds is related to antioxidant properties, since they are chemical structures that have hydroxyls and aromatic rings, in simple or polymer forms, which give them the antioxidant power. These compounds can be natural or synthetic. When present in vegetables they can be in free forms or complexed with sugars and proteins (ANGELO et al., 2007). Regarding the pharmacological properties, research on the anticarcinogenic or chemopreventive potential, antioxidant, antiplatelet and antithrombotic properties of cloves reinforce the popular use of this species (BANERJEE et al., 2006; KUBATKA et al 2017).

Flavonoids reveal an abundant presence. Corroborating with studies by Adaramola (2016), where the content of the Hydroalcoholic extract was higher $143,36 \mathrm{mg}^{\mathrm{EAT}} \mathrm{g}^{-1}$ that of essential oil125.36 $\mathrm{mg}^{\text {EAT g }}{ }^{-1}$ for having $70 \%$ methanol in its composition that has a low polarity favoring its greater yield.

The flavonoid compounds quantified previously, are known to have several biological activities, act as antioxidants in the inactivation of free radicals, and stand out in terms of the ability to act on inflammation, on the immune system, anticancer, antitumor, cardioprotection, antiAlzeimer, neuroprotective providing enormous pharmacological potential. Plants containing flavonoids have significant antimicrobial activity, which may be associated with their solubility and the assignment of hydroxyl phenolic groups, which have an affinity for proteins, acting as inhibitors of bacterial enzymes, as well as intervening in their synthesis pathways (COSTA et al ., 2018). 
The variations in the concentrations of total phenolics and total flavonoids occur due to different factors, such as flora ecology (PARK et al., 2002), by the period of collection (SANTOS et al., 2003).

\subsection{Thermodynamic stability}

Table 4 shows a study of the thermodynamic stability of nanoemulsion formulations with the essential oil and hydroalcoholic extract of Syzygium aromaticum.

Table 4 - Study of the thermodynamic stability of nanoemulsion formulations with the essential oil of Syzygium aromaticum

\begin{tabular}{lccccc}
\hline \multicolumn{1}{c}{ Identification } & SF & AQ & CG & DCG & Stability Final \\
\hline NEO1 1 & - & - & - & + & - \\
NEO 2 & - & - & - & - & - \\
NEO 3 & - & + & - & - & - \\
NEH 1 & - & - & - & + & + \\
NEH 2 & - & - & - & - & - \\
NEH 3 & - & + & - & - & \\
\hline
\end{tabular}

Source: Authors (2021)

Note: SF- phase separation or creaming at room temperature; AQ- phase separation after heating; CGphase separation or creaming after freezing; DCG- phase separation or creaming after thawing; + positive; - negative.

According to Table 4, it was determined as a result by means of the analyzes, that the best surfactant was exactly Tween 20, presenting a higher sensitivity when it comes to fungicidal activity. Through the work of Pontes \& Silvania (2013), the selection parameter for the best concentration of essential oil and surfactant for the synthesis of nanoemulsions was the elimination of concentrations that presented phase separations (instability) of the nanoemulsions, aiming at 
achieving more formulations stable. In the case of the formulations used, they did not present phase separations, however when they reached higher and lower temperatures, only the formulation NEO2 and $\mathrm{NEH} 2$ were stable for terms of applicability. Precisely because these nanoemulsions are described as stable systems.

\subsection{Antifungal activity}

Table 5 presents the antifungal activity of the essential oil, hydroalcoholic extract and nanoemulsions of Syzygium aromaticum

Table 5 - Antifungal activity of Syzygium aromaticum

\begin{tabular}{|c|c|c|c|c|c|c|}
\hline & \multicolumn{2}{|c|}{ Aspergillus niger } & \multicolumn{2}{|c|}{$\begin{array}{l}\text { Colletotrichum } \\
\text { gloeosporioides }\end{array}$} & \multicolumn{2}{|c|}{ Penicillium chrysogenum } \\
\hline & $\begin{array}{c}\text { CIM } \\
\mu g \mathrm{~mL}^{-1}\end{array}$ & $\begin{array}{c}\text { CFM } \\
\mu g \mathrm{~mL}^{-1}\end{array}$ & $\begin{array}{c}\text { CIM } \\
\mu \mathrm{g} \mathrm{mL^{-1 }}\end{array}$ & $\begin{array}{c}\text { CFM } \\
\mu g \mathrm{~mL}^{-1}\end{array}$ & $\begin{array}{c}\text { CIM } \\
\mu \mathrm{g} \mathrm{mL^{-1 }}\end{array}$ & $\begin{array}{c}\text { CFM } \\
\mu g \mathrm{~mL}^{-1}\end{array}$ \\
\hline EO & 100 & 250 & 100 & 250 & 250 & 300 \\
\hline $\mathrm{EH}$ & 100 & 250 & 250 & 300 & 250 & 300 \\
\hline NEO2 & 25 & 50 & 25 & 100 & 50 & 100 \\
\hline $\mathrm{NEH} 2$ & 50 & 100 & 50 & 100 & 100 & 250 \\
\hline
\end{tabular}

Source: Authors (2021)

Note: EO, essential oil; EH, hydroalcoholic extract; NEO2, nanoemulsion formulated with essential oil; CIM, Minimum Inhibitory Concentration; CFM, Minimum Fungicide Concentration.

According to Table 5, the Minimum Inhibitory Concentration test showed the result of inhibition of the microbial growth of $A$. niger from $100 \mu \mathrm{g} \mathrm{mL} \mathrm{mL}^{-1}, C$. gloesporioides from $100 \mu \mathrm{g} \mathrm{mL}^{-1}$ and $P$. chrysogenum from $250 \mu \mathrm{g} \mathrm{mL}-1$ for essential oil. For the hydroalcoholic extract, the Minimum Inhibitory Concentration test showed the result of inhibition of the microbial growth of $A$. niger from $100 \mu \mathrm{gL}^{-}$ 1, of $C$. gloesporioides from $250 \mu \mathrm{g} \mathrm{mL}^{-1}$ and of $P$. chrysogenum a from $250 \mu \mathrm{g} \mathrm{mL}^{-1}$ with the best performance in the fungus $A$. niger. For the essential oil nanoemulsion, 
the MIC was obtained of $25 \mu \mathrm{g} \mathrm{mL}^{-1}, 25 \mu \mathrm{g} \mathrm{mL}-1$ and $50 \mu \mathrm{g} \mathrm{mL} \mathrm{m}^{-1}$ for A. niger, $\mathrm{C}$. gloeosporioides and P. chrysogenum, respectively and for the hydroalcoholic extract nano, the result obtained was $50 \mu \mathrm{g} \mathrm{mL}^{-1}, 50 \mu \mathrm{g} \mathrm{mL}^{-1}$ and $100 \mu \mathrm{gL}^{-1}$ for $A$. niger, C. gloeosporioides and P. chrysogenum, respectively.

In a study by Meneze et al. (2009) on the antifungal activity of Syzygium aromaticum the authors reported that MIC from the concentration of $100 \mu \mathrm{gL}^{-1}$ is considered a good antifungal activity and from 101 to $500 \mu \mathrm{g} \mathrm{mL}^{-1}$ Moderate antifungal activity as we can see in Table 5 our results range from good antifungal activity to moderate, so we can consider Syzygium aromaticum to be a good inhibitor. Corroborating with previous studies by the authors Neto et al. (2017) and Ascensão \& Mouchrek Filho (2013).

The test for Minimum Fungicide Concentration showed good efficacy. For EO, the best result was in front of $A$. niger and in front of $C$. gloesporioides, with fungicidal action from $100 \mu \mathrm{g} \mathrm{mL}^{-1}$ already in the hydroalcoholic extract the best result was in front of $A$. niger with fungicidal action from $100 \mu \mathrm{m} \mathrm{mL}^{-1}$, as the essential oil nanoemulsion had a highlight in its performance in front of Aspergillus niger and in front of Colletotrichum gloeosporioides that showed inhibition in $25 \mu \mathrm{g} \mathrm{mL}^{-1}$ of both and the nanoemulsion of the hydroalcoholic extract had its best performance against Aspergillus niger and against Colletotrichum gloeosporioides which showed inhibition in $50 \mu \mathrm{g} \mathrm{mL}^{-1}$ both. In the study by Neto et al. (2017) and Costa et al. (2011) corroborate the results presented in this work, proving the efficiency of Syzygium aromaticum.

In short, nanoemulsions in this work had the most efficient performance when compared to essential oil and hydroalcoholic extract.Several recent researches have reported the formation of nanoemulsions as a strategy to improve the functionality and chemical property of its constituents, one of the efficiencies incorporated in a nanoemulsion is because it has smaller details that increases the permeability of the fungus membrane. Thus improving its antifungal capacity. 


\section{CONCLUSION}

In this work it was possible to prove the secondary metabolisms present in the buttons of $S$. aromaticum fact that influences the inhibition of microorganisms, pharmacological potential, biological and chemical properties. It was possible to demonstrate the levels of phenolics and total flavonoids being significant. The use of $S$. aromaticum for medicinal purposes it is very significant due to its wide applicability and its efficiency in the biotechnological product nanoemulsion used in this study against pathogenic fungi, showing to be an alternative to the current market for the combat and control of pathogenic fungi.

\section{ACKNOWLEDGMENTS}

I would like to thank the Laboratory of Research and Application of Essential Oils (LOEPAV / UFMA), to all those involved, in particular Gustavo O. Everton, Maria Giullia AC Felizardo, Thayane L. de Sousa and João Pedro M. Oliveira for their collaboration in this work.

\section{REFERENCES}

ADARAMOLA, B.; ONIGBINDE, A. Effect of extraction solvent on the phenolic content, flavonoid content and antioxidant capacity of clove bud. IOSR J Pharm Biol Sci, v. 11, n. 3, p. 33-8, 2016.

AFFONSO, Raphael S. et al. Aspectos químicos e biológicos do óleo essencial de cravo da índia. Revista Virtual de Química, v. 4, n. 2, p. 146-161, 2012.

ANGELO, Priscila Milene; JORGE, Neuza. Compostos fenólicos em alimentos-uma breve revisão. Revista do Instituto Adolfo Lutz (Impresso), v. 66, n. 1, p. 01-09, 2007.

ASCENÇÃO, Vanessa Louzeiro; MOUCHREK FILHO, Victor Elias. Extração, caracterização química e atividade antifúngica de óleo essencial Syzygium aromaticum (cravo da índia). Cadernos de Pesquisa, 2013.

ASSIS, Letícia Marques de et al. Revisão: Características de nanopartículas e potenciais aplicações em alimentos. Brazilian Journal of Food Technology, v. 15, n. 2, p. 99-109, 2012. 
BANERJEE, S. et al. Clove (Syzygium aromaticum), a potential chemopreventive agent for lung cancer. Carcinogenesis, v.77, n.8, p.1645-54, 2006.

Brasil M. S. (2006). Política Nacional de Plantas Medicinais e Fitoterápicos. Brasília: Ministério da Saúde.

COSTA, Jéssica Caroline Freitas da et al. Perfil fitoquímico e avaliação da atividade antimicrobiana de extratos aquoso e etanólico de folhas de Cecropia pachystachya. 2018.

DOWLD, L.E. Spectrophotometric determination of quercetin. Analytical Chemistry, v. 31, n. 7, p.1184-1187, 1959.

DE LIMA, Tamyres Carla Porteglio et al. DESENVOLVIMENTO DE NANOGEL DE Copaifera reticulata SOBRE A LESÃO MUSCULAR EM RATOS USANDO FONOFORESE. Saúde e Pesquisa, v. 13, n. 1, 2020.

DA SILVA, Nádia Livia Amorim; MIRANDA, Francisco Alberto Alencar; DA CONCEIÇÃO, Gonçalo Mendes. Triagem fitoquímica de plantas de Cerrado, da área de proteção ambiental municipal do Inhamum, Caxias, Maranhão. Scientia Plena, v. 6, n. 2, 2010.

DE BESSA, N. G. F. et al. Prospecção fitoquímica preliminar de plantas nativas do cerrado de uso popular medicinal pela comunidade rural do assentamento vale verde-Tocantins. Revista Brasileira de Plantas Medicinais, v. 15, n. 4, p. 692-707, 2013.

DE ALENCAR MENEZES, Tatiany Oliveira et al. Avaliação in vitro da atividade antifúngica de óleos essenciais e extratos de plantas da região amazônica sobre cepa de Candida albicans. Revista de Odontologia da UNESP, v. 38, n. 3, p. 184-91, 2009.

DA GRAÇA CARDOSO, Maria et al. Avaliação do potencial fungitóxico do óleo essencial de Syzygium aromaticum (L.) Merr \& Perry (cravo-da-índia). Tecno-Lógica, v. 11, n. 1, p. 11-14, 2007.

FREDERICE, R.; FERREIRA, A.P.G.; GEHLEN, M.H. Molecular Fluorescence in Silica Particles Doped with Quercetin-Al ${ }^{3+}$ Complexes. Journal of Brazilian Chemical Society, v. 21, n. 7, p. 1213-1217, 2010

GADIOLI, Izabel Lucena. Obtenção, caracterização química, propriedades antioxidantes e antimicrobianas de extratos de polpas, sementes e folhas de passifloras silvestres para formulação de nanoemulsões. 2017.

GHARSALLAOUI, Adem et al. Applications of spray-drying in microencapsulation of food ingredients: An overview. Food research international, v. 40, n. 9, p. 1107-1121, 2007.

HEMAISWARYA, S.; DOBLE, M. Synergistic interaction of eugenol with antibiotics against Gram negative bacteria. Phytomedicine, v. 16, n. 11, p. 997-1005, 2009. 
KUBITSCHEK-KM, Amapá-Rodovia Juscelino; ZERO, Jardim Marco. Development of jojoba oil (Simmondsia chinensis (Link) CK Schneid.) based nanoemulsions. Lat. Am. J. Pharm, v. 33, n. 3, p. 459-63, 2014.

KUBATKA, Peter et al. Antineoplastic effects of clove buds (Syzygium aromaticum L.) in the model of breast carcinoma. Journal of Cellular and Molecular Medicine, v. 21, n. 11, p. 28372851, 2017.

LUGASI, A. et al. Antioxidant and free radical scavenging properties of squeezed juice from blackradish (Raphanus sativus L. var niger) root. Phytotheraphy Research, v.12, n. 7, p. 502-506, 1998.

LORENZI, H.; MATOS, F.J.A. Plantas medicinais do Brasil: nativas e exóticas. Nova Odessa: Instituto Plantarum, 2002. 512p

LYRA, Luciana Pupo da Silveira. Desenvolvimento de nanoemulsão de geraniol e óleo essencial da palmarosa (Cymbopogon martinii) e sua ação inibitória sobre linhagens de Cutibacterium acnes. 2019.

MAEDA, Jocely Andreuccetti et al. Craveiro-da-índia: características físicas das sementes e seus efeitos na germinaçao e desenvolvimento vegetativo. Bragantia, v. 49, n. 1, p. 23-36, 1990.

MAZZARI, A. L. D. A.; PRIETO, Jose Maria. Monitoramento de interações farmacocinéticas entre plantas medicinais e fitoterápicos e os medicamentos convencionais pelo sistema de farmacovigilância brasileiro. Infarma, v. 26, p. 193-198, 2014.

MOREIRA, Ana Vládia Bandeira; MANCINI-FILHO, Jorge. Influência dos compostos fenólicos de especiarias sobre a lipoperoxidação e o perfil lipídico de tecidos de ratos. Revista de Nutrição, v. 17, n. 4, p. 411-424, 2004.

MARTINS, A.ndré Gustavo Lima de Almeida et al. Atividade antibacteriana do óleo essencial do manjericão frente a sorogrupos de Escherichia coli enteropatogênica isolados de alfaces. Ciência Rural, v. 40, n. 8, p. 1791-1796, 2010.

NETO, L. T. et al. AVALIAÇÃO DA AÇÃO ANTIFUNGICA DO ÓLEO ESSENCIAL DE Syzygium aromaticum SOBRE Aspergillus flavus. Anais do Salão Internacional de Ensino, Pesquisa e Extensão, v. 9, n. 11, 2018.

OLIVEIRA, A.C. et al. Fontes vegetais naturais de antioxidantes. Química Nova, v. 32, n. 3, p. 689-702, 2009.

ORNELAS, K. C. The Cambridge world history of food. Cambridge University Press, 2000.

OLIVEIRA, N. T. et al. Análise fitoquímica, citotóxica e antimicrobiana do extrato bruto etanólico das folhas da espécie Ambelania acida Aublet (Apocynaceae). Biota Amazônia (Biote Amazonie, Biota Amazonia, Amazonian Biota), v. 6, n. 1, p. 20-25, 2016. 
PAOLI, S. et al. Effects of clove (Caryophyllus aromaticus L.) on the labeling of blood constituents with technetium-99m and on the morphology of red blood cells. Brazilian archives of biology and technology, v. 50, n. spe, p. 175-182, 2007.

PULLE, D. A; Flora of Suriname 2 ed., Vol. III part. 2, Vereeniging Koloniaal Instituut te Amsterdam, 1942.

PARK, Y. K. et al. Própolis produzida no sul do Brasil, Argentina e Uruguai: Evidências fitoquímicas de sua origem vegetal. Ciência rural, v. 32, n. 6, p. 997-1003, 2002.

PEREIRA, A. A. et al. Caracterização química e efeito inibitório de óleos essenciais sobre o crescimento de Staphylococcus aureus e Escherichia coli. Ciência e Agrotecnologia, v. 32, n. 3, p. 887-893, 2008.

PARK, M. J. et al. Antifungal activities of the essential oils in Syzygium aromaticum (L.) Merr. Et Perry and Leptospermum petersonii Bailey and their constituents against various dermatophytes. The Journal of Microbiology, v. 45, n. 5, p. 460-465, 2007.

PONTES, S. F. O. et al. Desenvolvimento de nanoemulsões de óleos essenciais incorporadas em filme de metilcelulose para uso em alimentos. 2013.

RODRIGUES, E. C. R. et al. Development of a larvicidal nanoemulsion with Copaiba (Copaifera duckei) oleoresin. Revista Brasileira de Farmacognosia, v. 24, n. 6, p. 699-705, 2014.

RODRIGUES, K. A. F. et al. Prospecção fitoquímica e atividade moluscicida de folhas de Momordica charantia L. Cadernos de Pesquisa, v. 17, n. 2, 2010.

SUGUMAR, S. et al. Nanoemulsion of eucalyptus oil and its larvicidal activity against Culex quinquefasciatus. Bulletin of entomological research, v. 104, n. 3, p. 393-402, 2014.

SHAFIQ, S. et al. Development and bioavailability assessment of ramipril nanoemulsion formulation. European journal of pharmaceutics and biopharmaceutics, v. 66, n. 2, p. 227243, 2007.

SIMÕES, C. M. O. Farmacognosia: da planta ao medicamento. UFRGS; Florianópolis: UFSC, 2001.

SOCIEDADE BRASILEIRA DE CARDIOLOGIA. Revisão das II Diretrizes Brasileira de Cardiologia para o Diagnóstico e o Tratamento da Insuficiência Cardíaca. Arquivo Brasileiro de Cardiologia, 2002

TELES, Y. C. F.; SANTOS D. W.; LIMA, E. M. Evidências da relevância fitoquímica e biológica da família myrtaceae e do gênero Syzygium. CONAPESQ, p. 1-388-416.

WOISKI, R.G.; SLATINO, A. Analysis of propolis: some parameters and procedures for chemical quality control. Journal of Apicultural Research, v. 37, n. 2, p. 99-105, 1998 


\section{Authorship contributions}

\section{1 - Thaylanna Pinto de Lima}

Graduated in Chemistry

http://orcid.org/0000-0003-1172-3004 - thaylanna.lima@discente.ufma.br

Contributions: Conceptualization, Data Curation, Formal Analysis, Investigation, Methodology

\section{2 - Thayane Lopes de Sousa}

Graduated In Industrial Chemistry http://orcid.org/0000-0001-5383-9350 - thayane.lopes@discente.ufma.br Contributions: Conceptualization, Data Curation, Formal Analysis, Investigation, Methodology

\section{3 - Joao Pedro Mesquita Oliveira}

Graduated In Industrial Chemistry http://orcid.org/0000-0003-1833-9814 - jpm.oliveira@discente.ufma.br Contributions: Conceptualization, Data Curation, Formal Analysis, Investigation, Methodology

\section{4 - Maria Giullia Alves Carneiro Felizardo}

Graduated In Industrial Chemistry http://orcid.org/0000-0002-1921-9067 - giullia.73@hotmail.com

Contributions: Conceptualization, Data Curation, Formal Analysis, Investigation, Methodology

\section{5 - Gustavo Oliveira Everton}

Master in Health and Environment http://orcid.org/0000-0002-0457-914X - gustavooliveiraeverton@gmail.com Contributions: Conceptualization, Data Curation, Formal Analysis, Funding Acquisition, Investigation, Methodology, Project Administration

\section{6 - Victor Elias Mouchrek Filho \\ Professor http://orcid.org/0000-0003-2855-7292 - victor.mouchrek@ufma.br Contributions: Funding Acquisition, Project Administration}

\section{How to quote this article}

DE LIMA, T. P.; DE SOUSA, T. L.; OLIVEIRA, J. P. M.; FELIZARDO, M. G. A. C.; EVERTON G. O.; MOUCHREK FILHO, V. E.. Chemical profile, thermodynamic stability and fungicidal activity of the nanoemulsion incorporated with essential oil and hydroalcoholic extract of Syzygium aromaticum (L.) Merr. \& LM.Perry. Ciência e Natura, Santa Maria, v. 43, e77, p. 1-20, 2021. Disponível em: https://doi.org/10.5902/2179460X63929. 